University of Nebraska - Lincoln

DigitalCommons@University of Nebraska - Lincoln

Faculty Papers and Publications in Animal

Science

Animal Science Department

March 1986

\title{
GENETIC PARAMETER ESTIMATES FOR REPRODUCTIVE TRAITS OF MALE AND FEMALE LITTERMATE SWINE
}

\author{
R. O. Bates \\ Oklahoma Agricultural Experiment Station, Stillwater \\ D. S. Buchanan \\ Oklahoma Agricultural Experiment Station, Stillwater \\ R. K. Johnson \\ University of Nebraska-Lincoln, rjohnson5@unl.edu \\ R. P. Wetteman \\ Oklahoma Agricultural Experiment Station, Stillwater \\ R. W. Fent \\ Oklahoma Agricultural Experiment Station, Stillwat \\ See next page for additional authors
}

Follow this and additional works at: https://digitalcommons.unl.edu/animalscifacpub

Part of the Animal Sciences Commons

Bates, R. O.; Buchanan, D. S.; Johnson, R. K.; Wetteman, R. P.; Fent, R. W.; and Hutchens, L. K., "GENETIC PARAMETER ESTIMATES FOR REPRODUCTIVE TRAITS OF MALE AND FEMALE LITTERMATE SWINE" (1986). Faculty Papers and Publications in Animal Science. 40.

https://digitalcommons.unl.edu/animalscifacpub/40

This Article is brought to you for free and open access by the Animal Science Department at DigitalCommons@University of Nebraska - Lincoln. It has been accepted for inclusion in Faculty Papers and Publications in Animal Science by an authorized administrator of DigitalCommons@University of Nebraska - Lincoln. 


\section{Authors}

R. O. Bates, D. S. Buchanan, R. K. Johnson, R. P. Wetteman, R. W. Fent, and L. K. Hutchens 


\title{
GENETIC PARAMETER ESTIMATES FOR REPRODUCTIVE TRAITS OF MALE AND FEMALE LITTERMATE SWINE ${ }^{1}$
}

\author{
R. O. Bates ${ }^{2}$, D. S. Buchanan ${ }^{3}$, R. K. Johnson ${ }^{4}$, R. P. Wettemann ${ }^{3}$, \\ R. W. Fent ${ }^{5}$ and L. K. Hutchens ${ }^{3}$ \\ Oklahoma Agricultural Experiment Station, Stillwater 74078
}

\begin{abstract}
Reproductive traits of purebred and crossbred pigs produced in a four-breed diallel mating system using the Duroc, Landrace, Spotted and Yorkshire breeds were collected for five consecutive farrowing seasons (two farrowing seasons/year) beginning in fall 1976. Paternal half-sib heritabilities and genetic correlations for testicular traits ( 120 boars from 36 sires), serum testosterone (TE) and luteinizing hormone (LH) concentrations before and after treatment with gonadotropin releasing hormone (GnRH; 131 boars from 37 sires) and breeding performance traits (151 boars from 38 sires) were estimated. Heritability estimates were generally small to moderate except for sperm/gram testis (SGT), LH concentrations before (LHO) and at $3 \mathrm{~h}$ (LH3) after treatment with $\operatorname{GnRH}(.73 \pm .48,61 \pm .46$ and $1.19 \pm .45$, respectively). A large positive genetic correlation was found for LHO with $\mathrm{LH} 3(.94 \pm .39)$, while a negative relationship existed for LH3 with TE concentrations at $3 \mathrm{~h}$ after GnRH injection. The genetic correlation between a boar's average first service conception rate and average conception rate also was significant ( $82 \pm .54)$. Genetic correlations among littermate traits would suggest that selection for decreased age at puberty in gilts could cause an increase in LH concentrations in boar offspring, before and after GnRH injection, and may also have adverse effects on their ability to settle females. Selection for increased weight at puberty of gilts could cause TE concentrations of boar offspring to increase while having little effect on their breeding performance.

(Key Words: Boar, Heritability, Correlation, Testes, Puberty, Reproduction.)
\end{abstract}

\section{Introduction}

Many traits that are economically important to livestock production are sex-limited. It is difficult to identify individuals that are genetically superior for a sex-limited trait they do not express. The usual method of evaluating such individuals is the progeny test. This method yields a lower selection intensity than individual selection and increases the generation interval. A simpler and possibly more efficient

\footnotetext{
${ }^{1}$ Published Paper No. 4902 Journal Series, Oklahoma Agr. Exp. Sta., Stillwater and a contribution to Regional Project NC-103, Genetic Improvement of Efficiency in the Production of Quality Pork.

${ }^{2}$ Present address: Anim. Sci. Dept., Univ. of Missouri, Columbia 65211.

${ }^{3}$ Anim. Sci. Dept., Oklahoma State Univ., Stillwater 74078 .

${ }^{4}$ Present address: Anim. Sci. Dept., Univ. of Nebraska, Lincoln 68583 .

${ }^{5}$ Present address: Agr. Dept., Northeastern Oklahome A\&M College, Miami 74354.

Received November 18, 1985.

Accepted March 10, 1986.
}

method could be to select on an indicator trait(s) in the other sex [identify a trait(s) in one sex that is controlled by some of the same genes as those controlling the trait(s) in the sex of interest]. Ovulation rate in female mice has a high to moderate positive correlation with testis weight in males (Land, 1973; Islam et al., 1976). In breeds of sheep noted for female reproductive prolificacy, males had higher concentrations of plasma luteinizing hormone and greater testis growth at young ages (Land, 1973; Land and Carr, 1975). Brinks et al. (1978) reported a genetic correlation of -.71 between scrotal circumference in bulls and age at puberty in heifers. Workers with the Nebraska gene pool population reported a phenotypic correlation of .19 between excised testis weight of boars with the ovulation rate of their littermate sisters (Schinckel et al., 1983). The purpose of this study was to 1) estimate the relationship of testicular, endocrine and breeding performance traits of boars with the age and weight at puberty of their full-sib sisters and 2) to estimate heritabilities and genetic correlations for reproductive traits of boars. 


\section{Materials and Methods}

Data were collected for five consecutive farrowing seasons (two farrowing seasons/year) beginning in fall 1976 on purebred and twobreed cross boars and gilts produced in a fourbreed diallel mating scheme using the Duroc, Landrace, Spotted and Yorkshire breeds of swine. Animal management practices and a detailed account of data collection were reported by Hutchens et al. (1981, 1982). All gilts in a litter were measured for age and weight at puberty for the first four seasons only. Age at puberty (AP) was defined as the age in days when the first estrus was detected by a teaser boar. Estrous detection began when gilts completed gain test at approximately 90.7 $\mathrm{kg}$. Weight at puberty (WP) was the weight taken at the first estrus. The two heaviest boars at $42 \mathrm{~d}$ of age were left intact from each litter. One boar was randomly chosen for blood sampling and castration at 7 mo of age, and the breeding performance of the other boar was evaluated at the Southwestern Livestock and Forage Research Station, El Reno, Oklahoma.

Boars were bled by puncture of the venae cavae prior to, and at four hourly intervals after, treatment with $200 \mu \mathrm{g}$ (im) of gonadotropin releasing hormone $(\mathrm{GnRH} ; 131$ boars from 37 sires). Blood samples were later assayed for luteinizing hormone (LH) and testosterone (TE). The day following blood sampling, boars were castrated (except for the spring of 1978) and their right testis and epididymis were retained for evaluation (120 boars from 36 sires). Traits investigated were testicular weight (TWT), total testicular sperm number (TTS), total epididymidal weight (TEPW), total epididymidal sperm number (TEPS), sperm number/gram testis (SGT), total organ weight (TWT + TEPW, TOW) and total organ sperm number (TTS + TEPS, TOS). Plasma hormone ( $\mathrm{LH}$ and TE) concentrations used in the analysis were basal concentrations of TE (TEO) and $\mathrm{LH}$ ( $\mathrm{LHO}$ ) and at $3 \mathrm{~h}$ after $\mathrm{GnRH}$ injection (TE3 and LH3, respectively). Detailed experimental protocol and animal management were reported by Fent et al. (1983).

Purebred and two-breed cross boars retained for breeding were mated to two-breed cross sows and gilts (except for the spring of 1977 when only gilts were used) of dissimilar breed composition so that all possible three- and four-breed cross litters were produced. Virgin boars, approximately 7 mo of age, were used each of the five seasons. Throughout the experiment, 764 females were handmated to 151 boars representing 38 sires, 25 of which had both purebred and crossbred boar progeny represented. If a female returned to estrus she was bred to the boar used in the previous mating. Because females were mated to only one boar the female component of the breeding performance traits could not be evaluated. A service was defined as the exposure of a female to a boar during an estrous period. The average number of services per conception (ANSC), the percentage of females settled of females exposed (average conception rate, ACR) and average first service conception rate (FSCR) were determined for each sire for the 8-wk breeding season. A more complete description of data collection, animal management and the number of observations per breed of boar by breed of female subclass was given by Buchanan and Johnson (1984).

The following linear model for reproductive and breeding performance traits of boars was assumed:

$$
\begin{aligned}
y_{i j k l m}= & \mu+b_{i}+d_{j}+(b d)_{i j}+s_{k}+(b s)_{i k} \\
& +m_{1(i)}+e_{i j k l m},
\end{aligned}
$$

where:

$$
\begin{aligned}
y_{i j k l m}= & \text { an individual boar observation, } \\
\mu= & \text { an unknown fixed constant com- } \\
& \text { mon to all observations, } \\
b_{i}= & \text { fixed effect of the ith breed of sire } \\
& (i=1,2,3,4), \\
d_{j}= & \text { fixed effect of the jth breed of dam } \\
& (i=1,2,3,4), \\
(b d)_{i j}= & \text { the interaction between the ith } \\
& \text { breed of sire and the jth breed of } \\
& \text { dam, } \\
s_{k}= & \text { the fixed effect of the kth year- } \\
& \text { season farrowed }(k=1,2, \ldots, 5), \\
(b s)_{i k}= & \text { the interaction between the ith } \\
& \text { breed of sire and the kth year- } \\
& \text { season farrowed, } \\
m_{1(i)}= & \text { the random effect of the lth sire } \\
& \text { nested in the ith breed of sire and } \\
\mathrm{e}_{\mathrm{ijk} \mid \mathrm{m}=}= & \text { random residual effect peculiar to } \\
& \text { each observation. }
\end{aligned}
$$

After preliminary analyses, other two-way interactions among the fixed effects and the three-way interaction of breed of sire $x$ breed of dam $x$ year-season farrowed were found to 
be unimportant sources of variation and excluded from the model.

Estimates of variance and covariance components were calculated using Method 3 (Henderson, 1953). Paternal half-sib heritability $\left(h^{2}\right)$ estimates were calculated using the following formula :

$$
\mathrm{h}^{2}=4 \sigma_{\mathrm{s}}^{2} /\left(\sigma_{\mathrm{s}}^{2}+\sigma_{\mathrm{e}}{ }^{2}\right),
$$

where $\sigma_{\mathrm{s}}^{2}$ is the estimate of the sire variance component and $\sigma_{\mathrm{e}}{ }^{2}$ is the estimate of the residual variance component. Standard errors for heritability estimates were calculated using an approximation formula (Swiger et al., 1964). Genetic correlations $\left(r_{g}\right)$ of traits measured on the same animal were calculated using sire variance and covariance components as discussed by Falconer (1981). The formula is as follows:

$$
\mathrm{r}_{\mathrm{g}}=\sigma_{\mathrm{s}_{\mathrm{x}} \mathrm{s}} /\left(\sigma_{\mathrm{s}_{\mathrm{x}}}{ }^{2} \cdot \sigma_{\mathrm{s}_{\mathrm{y}}}{ }^{2}\right)^{1 / 2}
$$

where $\sigma_{\mathrm{S}_{\mathrm{x}} \mathrm{s}_{\mathrm{y}}}$ is the estimated covariance component among the additive gene effects for traits $\mathrm{x}$ and $\mathrm{y}, \sigma_{\mathrm{s} x}{ }^{2}$ and $\sigma_{\mathrm{sy}}{ }^{2}$ are the estimated variance components for the additive gene effects for traits $x$ and $y$, respectively. Approximate standard errors were calculated (Tallis, 1959).

Pooled, within-class correlation coefficients of AP and WP with boar testicular traits, hormone concentrations and breeding performance traits were calculated to determine the relationships among sex-limited traits between littermates. For AP and WP the record for each boar was paired with the mean of his full-sibs. There were 297 gilts included in the analysis. The total number of boars with female full-sib records available were 73 for the testicular data, 90 for the hormone data and 108 for the breeding performance data. Pooled, within-class correlation coefficients of breeding performance traits with testicular traits and hormone concentrations also were calculated. Because only two boars/litter were left intact, boar breeding performance records were paired with their brother's single observation. The number of boars with brothers available were 78 for the testicular data and 91 for the hormone data. The method of path coefficients (Wright, 1934) was used to estimate the genetic correlations among reproductive traits of littermates. Schinckel et al. (1983) used a similar method to estimate genetic correlations between sexspecific reproductive traits. Genetic correlations $\left(r_{g}\right)$ between male and female reproductive traits were estimated using the following:

$$
r_{g}=2 r_{f s} / h_{x} h_{y} n b,
$$

where $r_{f s}$ is the correlation between full-sibs for traits $x$ and $y, h_{x}$ and $h_{y}$ are the square roots of the estimated heritabilities for traits $x$ and $y$, respectively; $n$ is the harmonic mean of the number of full-sibs in each litter mean and $b$ is the standardized partial regression coefficient of the phenotypic mean of the litter on an individual observation. Genetic correlations among reproductive traits of littermate brothers were calculated using the same formula except that $n$ was equal to 1 .

\section{Results and Discussion}

Heritabilities. Breed comparisons and heterosis estimates for the boar reproductive traits are reported in Fent et al. (1983) and Buchanan and Johnson (1984). Heritabilities of boar reproductive traits are presented in table 1. Two traits (TWT and TOW) had negative estimates of the sire variance. This contrasts with literature estimates, which suggest that testis weight is a moderately heritable trait (Courot and Legault, 1977; Legault et al., 1979; Toelle et al., 1984). These negative estimates may be the result of decreases in the sire variance due to biases caused by the selection of the heaviest boars at $42 \mathrm{~d}$ of age to be left intact. The negative estimates of the sire variance could also be due to sampling because only 120 boars from 37 sires were measured. Other heritability estimates of testicular traits were low to moderate, except for SGT $(.73 \pm .48)$. This agrees with the report of .68 for sperm concentration (Masek et al., 1979) and suggests that improvement should occur when selecting for increased testicular sperm concentration; however, ease of measurement of this trait could be a limiting factor. The heritability for LHO was larger than that reported by Wettemann et al. (1980; $.61 \pm .46$ vs $.29 \pm .40$ ) for basal levels of plasma luteinizing hormone in gilts. Heritability estimates for LH and TE were greatest at $3 \mathrm{~h}$ after GnRH treatment of boars. In general, TE concentrations were moderate to lowly heritable, while LH concentrations had moderate to high estimates of heritability, suggesting that greater progress may occur when selecting for LH concentrations in comparison to TE concentrations. Heritability estimates of breeding per- 
formance traits were moderate in size; however, for these traits the standard errors of the estimates were as large or larger than the estimate itself.

Correlations. Genetic and phenotypic correlations of testicular traits and hormone concentrations are presented in tables 2 and 3, respectively, while genetic and phenotypic correlations of testicular traits with hormone concentrations are presented in table 4 . Phenotypic correlations among testicular traits were positive and ranged from .13 to .95 (table 2). Phenotypic correlations among $\mathrm{LH}$ and TE concentrations were small to moderate (table 3 ).

TABLE 1. ESTIMATED

HERITABILITIES $\left(h^{2}\right)$ AND SIRE VARIANCE COMPONENTS $\left(\sigma_{\mathrm{s}}{ }^{2}\right)$ FOR BOAR TRAITS

\begin{tabular}{lcc}
\hline Trait & $\sigma_{s}{ }^{2}$ & $h^{2}$ \\
\hline TWT $^{\mathrm{b}}$ & $\mathrm{NE}^{\mathrm{e}}$ & $\mathrm{NE}$ \\
TTS & 27.7968 & $.39 \pm .48$ \\
TEPW & 6.6922 & $.15 \pm .47$ \\
TEPS & 41.9987 & $.14 \pm .47$ \\
SGT & .0007 & $.73 \pm .48$ \\
TOW & NE & NE \\
TOS & 38.9064 & $.08 \pm .47$ \\
TEOc & .2212 & $.14 \pm .44$ \\
TE3 & 4.4028 & $.38 \pm .45$ \\
LH0 & .1033 & $.61 \pm .46$ \\
LH3 & .6185 & $1.19 \pm .45$ \\
ANSC & .0031 & $.24 \pm .37$ \\
ACR & .0034 & $.38 \pm .38$ \\
FSCR & .0017 & $.17 \pm .37$ \\
\hline
\end{tabular}

\footnotetext{
${ }^{a_{T W T}}=$ right testis weight $(\mathrm{g})$; TTS $=$ total testicular sperm number; $T E P W=$ total epididymal weight (g); TEPS = total epididymidal sperm number; $S G T=$ sperm number/gram testis; TOW = total organ weight (TWT + TEPW; g); TOS = total organ sperm number (TTS + TEPS); TEO = basal testosterone concentration; TE3 = testosterone concentration at $3 \mathrm{~h}$ after GnRH injection ; LHO = basal luteinizing hormone concentration; LH3 = luteinizing hormone concentration at $3 \mathrm{~h}$ after GnRH injection; ANSC = average number of services per conception; $A C R=$ average conception rate; FSCR = average first service conception rate.

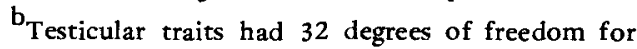
sires (dfs), 60 degrees of freedom for residual (dfres) and a sire variance component coefficient (k) of 2.542 .

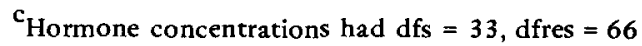
and $\mathrm{k}=2.619$.

$\mathrm{d}_{\text {Breeding performance traits had dfs }=34, \text { dfres }=}$ 85 and $\mathrm{k}=3.098$.

$\mathrm{e}_{\text {Nonestimable due to negative estimate of the sire }}$ variance component.
}

In general, the genetic correlations had standard errors larger than the estimates. The genetic correlations between TE 3 and differing LH concentrations and with TEO were negative. The genetic correlation of LHO with $\mathrm{LH} 3$ was positive, as well as with TEO (table 3 ). A greater number of genetic correlations between the testicular traits and $\mathrm{LH}$ concentrations were favorable (table 4) when compared with those genetic covariances between the testicular traits and TE concentrations (table 4). It may be that if selection for increased $\mathrm{LH}$ concentrations were practiced, TE produced by the interstitial cells of the testis would increase and cause increases in many of the testicular traits measured; however, selection for increased testosterone concentrations may result in suppression of $\mathrm{LH}$ secretion and possibly cause a decrease of several of the testicular traits measured. This may indicate that selection for changes in $\mathrm{LH}$ concentrations may also cause change in the sensitivity of the testis to $\mathrm{LH}$ and invoke change in the production of $T E$ and affect testicular maturation and sperm production. On the other hand, selection for TE does not appear to affect the sensitivity of the negative feedback mechanism on LH at the hypothalamic region, therefore selecting for increased testosterone concentrations may be selecting for greater efficiency of TE production by the testis but may have no effect on the negative feedback mechanism for LH secretion, and thus not alter testis function. This was substantiated by Schinckel et al. (1984), who suggested that genetic changes in testicular traits may be best influenced by genetic changes in $\mathbf{L H}$ concentrations.

Genetic and phenotypic correlations of breeding performance traits are presented in table 5. Average conception rate has a fairly strong favorable genetic correlation $(.82 \pm .54)$ with FSCR and all the phenotypic correlations were quite high.

Phenotypic and genetic correlations of the boar traits with the reproductive traits of male and female littermates are presented in tables 6,7 and 8 . The necessary heritabilities to calculate these genetic correlations were those estimated in this study, except for testis weight, which was not estimable; therefore, a weighted estimate of .61, developed from literature estimates (.34, Courot and Legault, 1977; .73, Legault et al., 1979), was used. The paternal half-sib heritability estimates used for AP and 
WP (.19 and .35 , respectively) were those reported by Hutchens et al. (1981).

The correlations of AP with TWT, TEPW and TOW $(-.13,-.02$ and -.11 , respectively; table 6) agree rather well with those reported by Schinckel et al. (1983). In this study, as well as the aforementioned study, these correlations were not significant. In general, AP apparently has little relationship with testicular traits (table 6) but is positively related to TE and negatively related to $\mathrm{LH}$ concentrations (table 7). It was positively associated with ACR and FSCR (.15 and .14 , respectively; table 8 ), and was negatively correlated with ANSC (-.15). In beef cattle, age at puberty in heifers has been found to be negatively related to scrotal cir- cumference of bulls at a similar age (Brinks et al., 1978; Lunstra, 1982). A positive relationship for WP exists with TEPW (.20), however; a negative relationship exists for WP with testicular and epididymal sperm counts $(-.16$ to -.20 ; table 7). Concentrations of TE are positively related to WP (.25 to .28$)$, but no relationship exists between $\mathrm{LH}$ concentrations and WP.

Little association was apparent between ANSC and the testicular traits (table 6); however, there was a positive relationship between conception rate (ACR and FSCR) and TEPS ( -.30 and .43 , respectively; table 6 ). Breeding performance traits of boars had no apparent association with TE concentrations; a small

TABLE 2. ESTIMATED CORRELATIONS AMONG BOAR TESTICULAR TRAITS

\begin{tabular}{lllllllr}
\hline \hline Traits & TWT & TTS & TEPW & TEPS & SGT & TOW & TOS \\
\hline TWT & & $-\mathrm{c}$ & - & - & + & - & - \\
TTS & $.44^{\mathrm{b}}$ & & $-.93(1.48)^{\mathrm{d}}$ & $-.45(1.19)$ & $1.12(.19)$ & - & $.38(1.48)$ \\
TEPW & .69 & .33 & & $-2.63(5.07)$ & $-.46(1.23)$ & - & $-3.52(11.47)$ \\
TEPS & .56 & .50 & .64 & $.06(1.48)$ \\
SGT & .13 & .92 & .09 & .30 & $-.07(1.14)$ & - & $.66(2.00)$ \\
TOW & .91 & .43 & .78 & .60 & .13 & - & $.87(2$. \\
TOS & .51 & .75 & .61 & .95 & .57 & .61 & - \\
\hline
\end{tabular}

\footnotetext{
${ }^{a_{T W T}}=$ right testis weight $(\mathrm{g}) ;$ TTS $=$ total testicular sperm number $;$ TEPW $=$ total epididymal weight (g); TEPS = total epididymidal sperm number SGT = sperm number/gram testis; TOW = total organ weight (TWT + TEPW; g); TOS = total organ sperm number (TTS + TEPS).

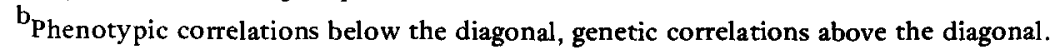

${ }^{\mathrm{c}}$ Sign of the additive genetic covariance.

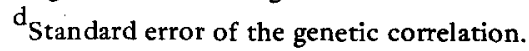

TABLE 3. ESTIMATED CORRELATIONS OF BOAR HORMONE CONCENTRATIONS BEFORE AND AFTER GONADOTROPIN RELEASING HORMONE TREATMENT

\begin{tabular}{|c|c|c|c|c|}
\hline Traits ${ }^{\mathrm{a}}$ & TEO & TE3 & LHO & LH3 \\
\hline TEO & & $-.85(1.34)^{\mathrm{C}}$ & $.46(1.26)$ & $.11(.92)$ \\
\hline TE3 & $.39^{b}$ & & $-.91 \quad(.98)$ & $-1.06(.70)$ \\
\hline LHO & .15 & -.04 & & $.94(.39)$ \\
\hline LH3 & -.01 & .16 & .33 & \\
\hline
\end{tabular}

\footnotetext{
${ }^{\mathrm{a}}$ TEO = basal testosterone concentration; TE3 = testosterone concentration at $3 \mathrm{~h}$ after GnRH injection; LHO = basal luteinizing hormone concentration; LH3 = luteinizing hormone concentration at $3 \mathrm{~h}$ after GnRH injection.

${ }^{b}$ Phenotypic correlations below the diagonal, genetic correlations above the diagonal.

${ }^{c}$ Standard error of the genetic correlation.
} 


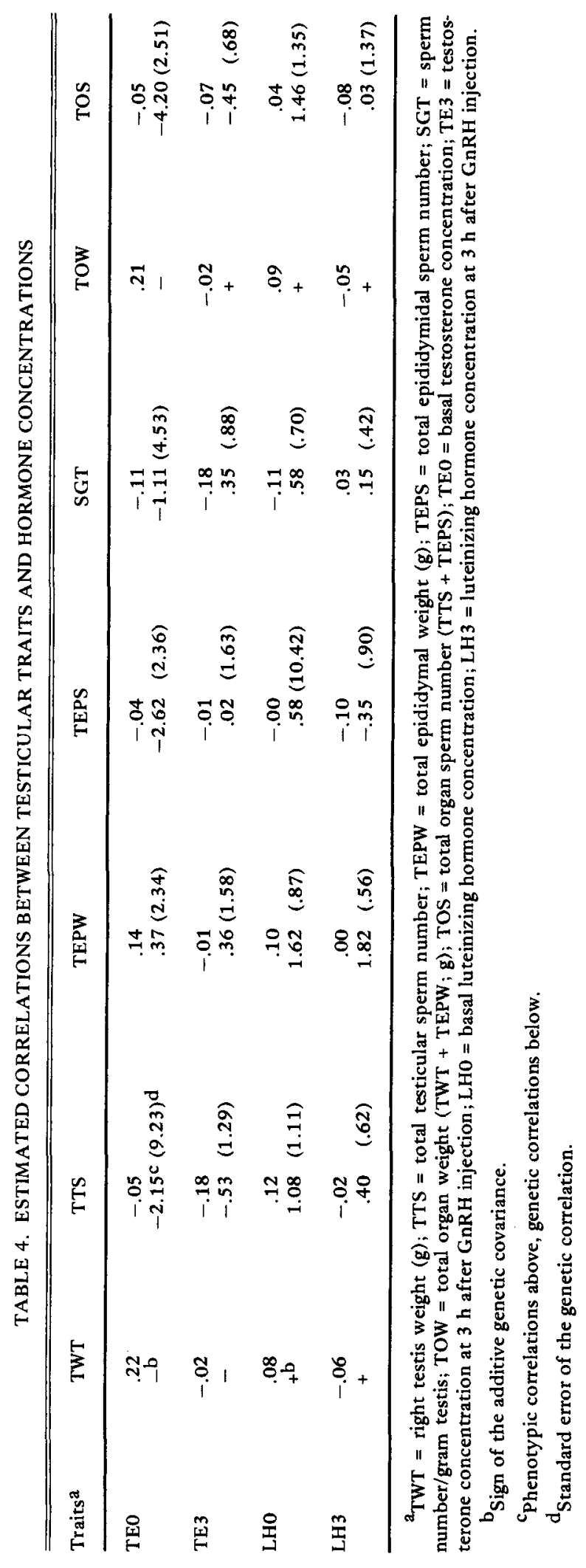


TABLE 5. ESTIMATED CORRELATIONS OF BREEDING PERFORMANCE TRAITS

\begin{tabular}{lllr}
\hline$=$ & & & \\
Traits $^{\mathrm{a}}$ & ANSC & ACR & FSCR \\
\hline ANSC & & $-.84(1.96)^{\mathrm{C}}$ & $-1.04(3.74)$ \\
ACR & $-.71^{\mathrm{b}}$ & & $.82(.54)$ \\
FSCR & -.98 & .70 &
\end{tabular}

${ }^{\mathrm{a}} \mathrm{ANSC}=$ average number of services per conception; $\mathrm{ACR}=$ average conception rate; FSCR = average first service conception rate.

${ }^{b}$ Phenotypic correlations below the diagonal, genetic correlations above the diagonal.

${ }^{c}$ Standard error of the genetic correlation. relationship existed between ACR and FSCR with LH3 (.23 and .24, respectively; table 8).

Favorable relationships did exist among the various reproductive traits and hormone concentrations reported. Selection for one of the more readily measurable traits (e.g., age and weight at puberty in gilts or breeding performance of boars) should cause a propitious response in the trait being selected for, while favorably changing many of the traits measured in the opposite sex. This may be even more pronounced if selection is for increased LH concentrations. Luteinizing hormone concentrations in the boar have been shown to be favorably correlated with many of the testis traits and

TABLE 6. ESTIMATED CORRELATIONS OF TESTICULAR TRAITS WITH LITTERMATE REPRODUCTIVE TRAITS

\begin{tabular}{lllccc}
\hline Boar \\
traits
\end{tabular}

${ }^{\text {a }}$ TWT $=$ right testis weight $(\mathrm{g}) ;$ TTS $=$ total testicular sperm number $;$ TEPW = total epididymal weight $(\mathrm{g}) ;$ TEPS = total epididymidal sperm number; SGT $=$ sperm number/gram testis; TOW $=$ total organ weight $($ TWT + TEPW; g); TOS = total organ sperm number (TTS + TEPS); AP = age at puberty (d) mean of littermate gilts; $\mathrm{WP}=$ weight at puberty $(\mathrm{kg})$ mean of littermate gilts; $\mathrm{ANSC}=$ average number of services per conception; ACR = average conception rate; FSCR = average first service conception rate.

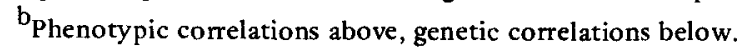

${ }^{c}$ Genetic correlations could not be estimated.

$t_{\mathbf{P}<10}$.

${ }^{*} \mathrm{P}<.05$.

${ }^{* *} \mathrm{P}<.01$. 
TABLE 7. ESTIMATED CORRELATIONS OF BOAR HORMONE CONCENTRATIONS WITH LITTERMATE REPRODUCTIVE TRAITS

\begin{tabular}{|c|c|c|c|c|c|}
\hline \multirow{2}{*}{$\begin{array}{l}\text { Boar } \\
\text { traits }\end{array}$} & \multicolumn{5}{|c|}{ Littermate traits ${ }^{2}$} \\
\hline & $\mathrm{AP}$ & WP & ANSC & ACR & FSCR \\
\hline TEO & $\begin{array}{l}.15^{b} \\
.80\end{array}$ & $\begin{array}{l}.28 * * \\
1.09\end{array}$ & $\begin{array}{r}.24 \\
2.62\end{array}$ & $\begin{array}{l}-.01 \\
-.09\end{array}$ & $\begin{array}{l}-.05 \\
-.65\end{array}$ \\
\hline TE 3 & $\begin{array}{l}.15 \\
.62\end{array}$ & $\begin{array}{l}.25 * * \\
.76\end{array}$ & $\begin{array}{r}-.18 \\
-1.19\end{array}$ & $\begin{array}{l}.00 \\
.02\end{array}$ & $\begin{array}{r}.16 \\
1.25\end{array}$ \\
\hline LHO & $\begin{array}{l}-.02 \\
-.07\end{array}$ & $\begin{array}{l}.16 \\
.43\end{array}$ & $\begin{array}{l}.11 \\
.58\end{array}$ & $\begin{array}{l}.09 \\
.37\end{array}$ & $\begin{array}{l}-.07 \\
-.44\end{array}$ \\
\hline LH3 & $\begin{array}{l}-.09 \\
-.28\end{array}$ & $\begin{array}{l}.15 \\
.34\end{array}$ & $\begin{array}{l}-.20 \\
-.75\end{array}$ & $\begin{array}{l}.23 \\
.68\end{array}$ & $\begin{array}{r}.24 \\
1.07\end{array}$ \\
\hline
\end{tabular}

${ }^{\mathrm{a}} \mathrm{TEO}=$ basal testosterone concentration $; \mathrm{TE3}=$ testosterone concentration at $3 \mathrm{~h}$ after $\mathrm{GnRH}$ injection; LHO = basal luteinizing hormone concentration LH3 = luteinizing hormone concentration at $3 \mathrm{~h}$ after $\mathrm{GnRH}$ injection; $A P=$ age at puberty (d) mean of littermate gilts; WP = weight at puberty (kg) mean of littermate gilts; ANSC = average number of services per conception; $A C R=$ average conception rate $;$ FSCR $=$ average first service conception rate.

${ }^{b}$ Phenotypic correlations above, genetic correlations below.

$* * \mathbf{P}<.01$.

TABLE 8. ESTIMATED CORRELATIONS

OF BOAR BREEDING PERFORMANCE TRAITS WITH AGE AND WEIGHT AT PUBERTY MEANS OF LITTERMATE GILTS

\begin{tabular}{lll}
\hline $\begin{array}{l}\text { Female } \\
\text { traits }\end{array}$ & $\begin{array}{l}\text { Age at } \\
\text { puberty } \\
(\mathrm{d})\end{array}$ & $\begin{array}{l}\text { Weight at } \\
\text { puberty } \\
(\mathrm{kg})\end{array}$ \\
\hline $\begin{array}{l}\text { Male traits } \\
\text { ANSC }\end{array}$ & $\begin{array}{l}-.15 b \dagger \\
-.70\end{array}$ & -.04 \\
ACR & $.15 t$ & -.14 \\
& .62 & .11 \\
FSCR & $.14 t$ & .33 \\
& .71 & .01 \\
\hline
\end{tabular}

\footnotetext{
${ }^{a} \mathrm{ANSC}=$ average number of services per conception; $A C R=$ average conception rate; FSCR = average first service conception rate.

${ }^{\mathrm{b}}$ Phenotypic correlations above, genetic correlations below.

${ }^{\dagger} \mathbf{P}<.10$.
}

also with AP of littermate gilts and breeding performance of littermate brothers. Luteinizing hormone concentrations also were moderately heritable in both boars and gilts, thus a more noticeable selection response would be expected. Therefore $\mathrm{LH}$ concentrations in the male have a major role in the reproductive function of the male and are related to the control of reproductive function of related females.

\section{Literature Cited}

Brinks, J. S., M. J. McInerney and P. J. Chenoweth. 1978. Relationship of age at puberty in heifers to reproductive traits in young bulls. Proc. West. Sec. Amer. Soc. Anim. Sci. 29:28.

Buchanan, D. S. and R. K. Johnson. 1984. Reproductive performance for four breeds of swine: Crossbred females and purebred and crossbred boars. J. Anim. Sci. 59:948.

Courot, M. and C. Legault. 1977. Genetic analysis of sperm production in young Large White boars: Preliminary results. A nim. Breed. Abstr. 46:98.

Falconer, D. S. 1981. Introduction to Quantitative Genetics (2nd Ed.). Longman Inc., New York, NY. 
Fent, R. W., R. P. Wettemann and R. K. Johnson. 1983. Breed and heterosis effects on testicular development and endocrine function of puberal boars. J. Anim. Sci. 57:425.

Henderson, C. R. 1953. Estimation of variance and covariance components. Biometrics 9:226.

Hutchens, L. K., R. L. Hintz and R. K. Johnson. 1981. Genetic and phenotypic relationships between pubertal and growth characteristics of gilts. J. Anim. Sci. 53:946.

Hutchens, L. K., R. L. Hintz and R. K. Johnson. 1982. Breed comparisons for age and weight at puberty in gilts. J. Anim. Sci. 5 5:60.

Islam, A. B., M. Mafizul, W. G. Hill and R. B. Land. 1976. Ovulation rate of lines selected for testis weight. Genet. Res, 27:23.

Land, R. B. 1973. The expression of female sex-linked characters in the male. Nature 241:208.

Land, R. B. and W. R. Carr. 1975. Testis growth and plasma LH concentration following hemicastration and its relation with female prolificacy in sheep. J. Reprod. Fertil. 45:495.

Legault, C., J. Gruand and F. Oulion. 1979. Development and genetic value of an in vivo method of estimating testis weight in young boars. Anim. Breed. Abstr. 48:26.

Lunstra, D. D. 1982. Testicular development and onset of puberty in beef bulls. MARC Beef Res. Program Progress Rep. No. 1 pp 26-27.

Masek, N., J, Kuciel and L. Pospichal. 1979. Genetic analysis of strained ejaculate volume and sperm concentration of boars in artificial insemination. Anim. Breed. Abstr. 49:253.

Schinckel, A., R. K. Johnson, R. A. Pumfrey and D. R. Zimmerman. 1983. Testicular growth in boars of different genetic lines and its relationship to reproductive performance. J. Anim. Sci. 56:1065.

Schinckel, A. P., R. K. Johnson and R. J. Kittok. 1984. Testicular development and endocrine characteristics of boars selected for either high or low testis size. J. Anim. Sci. 58:675.

Swiger, L, A., W. R. Harvey, D. O. Everson and K. E. Gregory. 1964. The variation of intraclass correlation involving groups with one observation. Biometrics 20:818.

Tallis, G. M. 1959. Sampling errors of genetic correlation coefficients calculated from analysis of variance and covariance. Aust. J. Statist. $1: 35$.

Toelle, V. D., B. H. Johnson and O. W. Robison. 1984. Genetic parameters for testes traits in swine. J. Anim. Sci. 59:967.

Wettemann, R. P., R. K. Johnson and I. T. Omtvedt. 1980. The relationship between plasma progesterone and LH and the number of corpora lutea and embryos in purebred and crossbred gilts. $J$. Anim. Sci. 51:1352.

Wright, S. 1934. The method of path coefficients. Ann. Math. Statist. 5:161. 